\title{
PEMBERDAYAAN SUMBER DAYA MANUSIA APARATUR PADA BADAN KEPEGAWAIAN DAERAH PROVINSI SUMATERA SELATAN
}

\author{
Holipah $^{1}$, Asmawati ${ }^{2}$ \\ $\left.{ }^{1}\right)$ Sekolah Tinggi Ilmu Administrasi (STIA) Satya Negara Palembang \\ ${ }^{2}$ )Sekolah Tinggi Ilmu Administrasi (STIA) Satya Negara Palembang
}

Email : $\underline{\text { Holipahyunani@gmail.com, asmawati040482@gmail.com }}$

\begin{abstract}
In an organization, human resources have a crucial role to determine the achievement of organizational goals. Therefore, this study aims to determine the empowerment of human resources personnel at the Regional Employment Board of Central South Sumatra Province. The method used is descriptivequantitative method. To obtain the data in forming a generalization, a number of samples and informants were used. The results shows that the empowerment of human resources personnel at the Regional Employment Board of Central South Sumatra Province is categorized 'Good', in which the average percentage score of all aspects are being reviewed as $77.42 \%$. Nevertheless, there is still an aspect that needs to be noted that is the value of leadership, particularly leader's justice in making decisions about the provision of learning tasks that should be more objective.
\end{abstract}

Keywords: empowerment, human resources, regional employment board.

\section{Pendahuluan}

Dalam suatu organisasi, baik itu organisasi swasta maupun organisasi publik sumber daya manusia mempunyai peranan yang sangat krusial untuk menentukan pencapaian tujuan organisasi bila dibandingkan dengan sumber daya lain yang dimiliki oleh organisasi. Manusia bisa menjadi akar persoalan atau kegagalan organisasi apabila tidak dapat diberdayakan dengan baik, dan ditingkatkan potensi-potensi yang dimilikinya. Sebaliknya manusia merupakan pusat segala keberhasilan dari pada organisasi apabila proses pemberdayaan dalam organisasi berjalan dan dilakukan dengan perencanaaan menyelunuh serta prosedur yang jelas. Untuk itu, memberdayakan pegawai (employee empowerment) saat ini merupakan sesuatu modal dan hal yang sangat penting bagi setiap organisasi guna menghasilkan Sumber Daya Manusia yang memiliki daya saing tinggi serta menunjang keberlangsungan pencapaian tujuan organisasi secara efektif dan efisien. Namun demikian, dalam penelitian ini nantinya peneliti membatasi diri dan hanya berfokus pada bagaimana pemberdayaan diimplementasikan melalui salah satu program/kegiatan pengembangan SDM di Badan Kepegawaian Daerah Provinsi Sumatera Selatan. Badan Kepegawaian Daerah Provinsi Sumatera Selatan merupakan salah satu lembaga teknis pemerintah yang ada di Provinsi Sumatera Selatan 
yang memiliki fungsi untuk memberikan pelayanan yang berhubungan dengan segala urusan kepegawaian dimulai dari hal perencanaan, penerimaan, seleksi, penempatan, pelatihan, pemeliharaan, pengembangan, sampai pada pemberhentian. Berdasarkan tugas pokok dan fungsi (Tupoksi) yang melekat pada Badan Kepegawaian Daerah Provinsi Sumatera Selatan tentunya tidak mudah untuk mempertahankan eksistensi baik itu pengetahuan, keterampilan (skill) sumber daya manusia yang ada di organisasi tersebut. Maka dari itu, lembaga teknis ini benarbenar harus memiliki kualitas kepemimpinan yang baik, kualitas pekerja yang baik sehingga nantinya secara komperenshif kebutuhan akan pemberdayaannya terimplementasi dengan baik. Oleh karena itu, penelitian ini ingin mengetahui pemberdayaan sumber daya manusia aparatur pada Badan Kepegawaian Daerah Provinsi Sumatera Selatan.

\section{METODE PENELITIAN}

Tipe penelitian ini adalah kuantitatifdeskriptif. Penelitian berlokasi di Kantor Badan Kepegawaian Daerah Provinsi Sumatera Selatan. Populasi dan Sampel Populasi adalah selunuh pegawai pada Kantor Badan Kepegawaian Daerah Provinsi Sumatera Selatan. Sampel sebanyak 93 orang yang diplih secara nonpropability sampling melalui sampling insidental. Datanya dikumpulkan melalui penyebaran angket, wawancara dan observasi.

Pengolahan data menggunakan sistem tabulasi data dengan memakai analisis frekuensi sederhana dengan rumus:
$P=\frac{f}{n} x 100$

Untuk menentukan presentase jawaban:

\section{Nilai Skor $(N)=$ Bobotx Nilai}

Untuk menentukan persentase skor.

Skor \% $=\frac{\text { Skor yang dicapai }}{\text { Skor ideal }} X 100$

Untuk menentukan nilai rata-rata skor :

Nilai Rata-rata Skor \%=

$\frac{\text { G Skor } \phi_{6}}{\text { Jumlah Butir Pertanyaar }}$

Adapun kriteria interprestasi skor yang digunakan antara 81-100 kategori sangat baik, skor antara 61-80 kategori baik, skor antara 41-60 kategori cukup baik, skor antara 21-40 kategori kurang baik,dan skor antara 0-20 kategori tidak baik. Data kemudian dipaparkan secara deskriptif dan diinterpretasikan berlandaskan teori.

\section{HASIL PENELITIAN}

\section{Nilai Kepemimpinan (Leadership Values)}

\section{Adil}

Berdasarkan hasil tanggapan responden maka dapat diketahui bahwa keadilan pimpinan dalam membuat keputusan khususnya dalam peningkatan pendidikan melalui pemberian tugas belajar maupun izin belajar sudah sangat dirasakan oleh beberapa pegawai yang ada di Badan Kepegawaian Daerah Provinsi Sumatera Selatan. Namun demikian, tidak seluruhnya pegawai merasakan hal yang sama. Hal ini dapat terlihat bahwa masih terdapat beberapa pegawai yang menjawab pimpinan kurang adil bahkan tidak adil 
dalam membuat keputusan khususnya meningkatkan pendidikan melalui pemberian tugas belajar/izin belajar. hal ini menandakan bahwa dari beberapa persepsi pegawai tersebut berarti masih terdapat masalah dalam hal keadilan pimpinan dalam membuat keputusan khususnya terkait dengan peningkatan pendidikan melalui pemberian tugas belajar/izin belajar pegawai. Dengan demikian, ini berarti bahwa dalam memberdayakan pegawai dengan meningkatkan pendidikannya melalui pemberian tugas belajar/izin belajar pada Badan Kepegawaian Daerah Provinsi Sumatera Selatan masih perlu mendapat perhatian dan dilakukan evaluasievaluasi atau pertimbanganpertimbangan khusus yang lebih objektif agar selunuh pegawai benarbenar merasa diberdayakan sebagaimana mestinya.

\section{Berani}

Berdasarkan hasil tanggapan responden dapat diketahui bahwa ketegasan pimpinan dalam mengambil keputusan hampir seluruhnya telah di rasakan oleh para pegawai. Hal ini menandakan bahwa pimpinan telah bersikap tegas dalam beberapa pengambilan keputusan terkait beberapa hal-hal menyangkut pegawai dan kepentingan organisasi. Ini tentunya menjadi keunggulan organisasi karena pimpinan tidak memiliki sedikitpun keragu-raguan dalam mengambil keputusan. Dengan demikian, ini menunjukan bahwa ketegasan sikap yang dimiliki oleh pimpinan dalam beberapa pengambilan keputusan sudah berjalan dengan baik dan tentunya hal ini akan berdampak positif terhadap pegawai untuk lebih berdaya dalam bertindak dan melaksanakan tugas pekerjaan sehari-hari.

\section{Bersediamenerima}

Berdasarkan hasil tanggapan responden, dapat diketahui bahwa dari persepsi responden/pegawai mengenai kesediaan pimpinan dalam menerima dan menghargai pendapatpendapat atau ide-ide yang disampaikan para pegawai sudah berjalan atau terbilang baik karena hampir selunuhnya para responden/pegawai menjawab bahwa pimpinan benar-benar bersedia menerima dan menghargai mereka dalam mengemukakan pendapat-pendapat yang dapat membangun organisasi kedepan. Dengan demikian hal ini menjadi salah satu keunggulan Badan Kepegawaian Daerah Provinsi Sumatera Selatan karena pimpinan telah berupaya memberdayakan pegawai melalui kesediaan pimpinan untuk menerima dan menghargai pendapat-pendapat atau saran-saran yang konstruktif dari para pegawai untuk kemajuan organisasi kedepan. Hal ini menjadi catatan bagi pimpinan agar tetap dipertahankan bila perlu ditingkatkan.

\section{Teladan Pimpinan}

Berdasarkan hasil tanggapan responden, dapat diketahui bagaimana penilaian responden/pegawai terhadap keteladanan yang ditunjukan oleh pimpinan. Hal ini terlihat jelas bahwa hampir secara keselunuhan persepsi para pegawai mengenai keteladanan yang ditunjukan oleh pimpinan mereka adalah baik. Dengan persepsi para responden/pegawai tersebut maka Sudah barang tentu ini akan menjadi salah satu kekuatan dari organisasi karena dengan pendapat 
pegawai tentang keteladanan pimpinan mereka yang baik, ini akan menjadi mudah untuk pimpinan membimbing serta mengarahkan selunh pegawai bekerja lebih proaktif demi mencapai tujuan organisasi. Dengan demikian keteladanan yang ditunjukan oleh pimpinan berpengaruh besar terhadap selunuh pegawai dalam melaksanakan tugas pekerjaannya masing-masing. Hal ini menjadi salah satu kekuatan bagi organisasi khususnya Badan Kepegawaian Daerah Provinsi Sumatera Selatan karena pimpinan mampu menunjukan keteladanannya dengan baik.

\section{Motivasi Pimpinan}

Berdasarkan hasil tanggapan responden, dapat diketahui bahwa hampir selunuh responden/pegawai berpendapat bahwa pimpinan telah memberikan motivasi kepada mereka dalam melaksanakan tugas pekerjaannya. Hal ini menandakan berarti pimpinan terus berupaya memberikan dukungan (support) melalui motivasimotivasi yang kuat kepada selunuh pegawai yang ada pada Badan Kepegawaian Daerah Provinsi Sumatera Selatan yang tentunya kesemua ini akan berdampak pada semangat kerja pegawai dalam melaksanakan tugas pekerjaannya sehari-hari. Dengan demikian ini berarti bahwa perhatian pimpinan terhadap pegawai dengan cara memberikan motivasi telah dilakukan dengan baik. Hal ini menandakan bahwa pimpinan telah memberdayakan pegawai melalui pemberian motivasi-motivasi yang kuat yang berdampak khusus kepada para pegawai serta organisasi secara keselunuhan.

\section{Distribusi jawaban responden terhadap aspek Nilai Kepemimpinan (Leadership values)}

Untuk menjawab bagaimana pemberdayaan sumber daya manusia aparatur pada Badan Kepegawaian Daerah Provinsi Sumatera Selatan ditinjau dari aspek Nilai Kepemimpinan

(Leadership Values) maka dapat diketahui bahwa presentase jawaban responden masing-masing indikator yaitu pada pertanyaan indikator satu berada pada $60,33 \%$, kemudian pertanyaan indikator dua berada pada $79,34 \%$, pertanyaan indikator tiga berada pada 79,02\%, pertanyaan indikator empat berada pada 78,69\%, dan pertanyaan indikator lima berada pada 79,67\% Bahwa dari 5 (lima) pertanyaan yang berhubungan dengan nilai kepemimpinan (Leadership Values), penyebaran jawaban responden dari persentase skor berada antara 60,33\% sampai 79,67\%, jumlah persentase skor adalah 377,05 sehingga persentase nilai rata-rata skor adalah $377,05 / 5=75,41$. Dengan demikian ini berarti bahwa pemberdayaan sumber daya manusia aparatur pada Badan Kepegawaian Daerah Provinsi Sumatera Selatan ditinjau dari Nilai Kepemimpinan (Leadership Values) berada pada kategori Baik.

\section{Nilai Profesional (Professional Values) \\ Pengetahuan}

Berdasarkan hasil tanggapan responden, dapat diketahui bahwa secara umum hampir eluruh responden/pegawai menyatakan bahwa wawasan pimpinan mempertimbangkan segala aspek dalam menentukan kebijakan yang ada di organisasi sudah terbilang baik. Hal ini menandakan bahwa 
pimpinan benar-benar mempertimbangkan terlebih dahulu segala aspek sebelum menentukan kebijakan. Dengan demikian, hal ini berarti bahwa wawasan pimpinan untuk mempertimbangkan aspek dalam menentukan beberapa kebijakan pada Badan Kepegawaian Daerah Provinsi Sumatera Selatan terbilang baik. Maka dari itu, hal ini perlu dipertahankan bila perlu ditingkatkan .

\section{Memiliki Daya Cipta}

Berdasarkan hasil tanggapan responden, dapat diketahui bahwa upaya yang dilakukan pimpinan dalam memberi dorongan kepada selunuh pegawai untuk menemukan sesuatu yang baru dan bermanfaat bagi organisasi hampir selunuhnya telah dirasakan oleh beberapa pegawai. Hal ini menandakan berarti kepedulian pimpinan dalam mendorong pegawai untuk menemukan hal baru yang bermanfaat bagi organisasi telah dilaksanakan dengan baik. Dengan demikian ini menandakan akan perhatian pimpinan dalam mendorong para pegawai untuk menemukan halhal baru yang bermanfaat bagi organisasi kedepan telah dilaksanakan dengan baik. Otomatis hal ini akan menjadikan para pegawai lebih berdaya dalam bekerja dari sebelumnya.

\section{Bertanggung Jawab}

Berdasarkan hasil tanggapan responden, dapat diketahui dan dimaknai bahwa dari persepsi pegawai mengenai tanggungjawab pimpinan atas setiap permasalahan yang terjadi dalam organisasi sudah terbilang baik. Hal ini terlihat hampir dari selunuh jawaban responden/pegawai menjawab bahwa pimpinan telah bertanggung jawab atas setiap permasalahan yang terjadi dalam organisasi. Dengan demikian, dapat diketahui dan dimaknai bahwa bentuk tanggung jawab yang ditunjukan oleh pimpinan selama ini dalam menyelesaikan setiap permasalahanpermasalahan yang terjadi dalam organisasi terbilang baik ini perlu dipertahankan dan ditingkatkan.

\section{Tidak Memihak}

Berdasarkan hasil tanggapan responden, dapat diketahui dan dimaknai bahwa dari persepsi pegawai mengenai pimpinan yang bersikap netral (tidak memihak) dalam menyelesaikan setiap permasalahan yang terjadi di organisasi hampir selunuhnya dirasakan oleh para pegawai. Hal ini menandakan bahwa dalam penyelesaian setiap permasalahan yang terjadi dalam organisasi pimpinan terus berupaya dan berusaha bersikap netral. Dengan demikian, dapat diketahui dan dipahami bahwa upaya pimpinan untuk tidak memihak atau bersikap netral dalam setiap penyelesaian permasalahan yang terjadi diorganisasi sudah berjalan dengan baik.

\section{Distribusi jawaban responden terhadap Nilai Profesional (Proffesional Values)}

Setelah melihat tabel distribusi frekuensi jawaban responden di atas, maka dapat diketahui bahwa presentase jawaban responden masingmasing indikator yaitu pada pertanyaan indikator satu berada pada $78,03 \%$, kemudian pertanyaan indikator dua berada pada $78,36 \%$, pertanyaan indikator tiga berada pada $79,34 \%$, dan pertanyaan indikator empat berada pada $77,38 \%$, dapat diketahui bahwa dari 4 (empat) pertanyaan yang berhubungan dengan nilai profesional (Proffesional Values), penyebaran jawaban responden dari persentase skor berada antara 77,38\% sampai 
79,34\% dimana jumlah persentase skor adalah $313,11 \%$ sehingga persentase nilai rata-rata skor adalah 313,11/4 = 78,28. Dengan demikian, ini berarti bahwa pemberdayaan sumber daya manusia aparatur pada Badan Kepegawaian Daerah Provinsi Sumatera Selatan ditinjau dari nilai profesional (Proffesional Values) berada pada kategori Baik.

\section{Nilai Umum(Universal Values)}

\section{Berterima kasih}

Berdasarkan hasil tanggapan responden, dapat diketahui bahwa hampir secara keseluruhan dari jawaban responden/pegawai mengenai rasa terima kasih yang diberikan pimpinan melalui pemberian penghargaan (reward) kepada para pegawai yang menyelesaikan tugas pekerjaan dengan baik atau berprestasi telah dilaksanakan dengan baik. Hal ini tentunya dapat menjadi salah satu kekuatan sekaligus motivasi khususnya para pegawai untuk dapat meningkatkan kinerja mereka lebih baik lagi dalam organisasi. Dengan demikian ini menandakan bahwa perhatian pimpinan berterimakasih dalam bentuk penghargaan atau reward kepada mereka pegawai yang dianggap pantas dan layak untuk menerima penghargaan tersebut telah berjalan dengan baik dan perlu dipertahankan serta ditingkatkan lagi.

\section{Kepercayaan}

Berdasarkan hasil tanggapan responden, dapat diketahui bahwa kepercayaan yang diberikan pimpinan dalam melaksanakan tugas/pekerjaan terhadap para pegawai sudah terbilang baik. Hal ini terlihat dari hampir selunuh responden/pegawai yang menjawab bahwa pimpinan telah memberikan mereka kepercayaan dalam melaksanakan tugas pekerjaan. Berarti ini menandakan pemberian kepercayaan oleh pimpinan terhadap pegawai dalam melaksanakan tugas pekerjaan tidak terdapat permasalahan. Dan ini dapat menjadi keuntungan bagi organisasi karena dengan pemberian kepercayaan penuh dari pimpinan kepada para pegawai untuk melaksanakan tugas pekerjaan akan membangkitkan komitmen pegawai, rasa percaya diri pegawai, dalam mengeksplorasi kelebihankelebihan mereka dalam bekerja. Dengan demikian ini berarti bahwa proses pemberdayaan pegawai yang dilakukan pimpinan melalui upaya pemberian kepercayaan kepada seluruh pegawai dalam melaksanakan tugas pekerjaan sudah berjalan dan telah dilaksanakan dengan baik sehingga perlu ditingkatkan dan dipertahankan.

\section{Bertaqwa kepada Tuhan}

Berdasarkan hasil tanggapan responden, dapat diketahui hampir selunuh responden/pegawai telah merasakan bagaimana pimpinan mengingatkan mereka bahwa keberhasilan tugas pekerjaan yang diraih selama ini adalah tidak terlepas dari campur tangan tuhan yang maha kuasa. Hal ini menandakan perhatian pimpinan untuk mengingatkan para pegawai akan hal ini sudah terbilang baik. Dengan demikian dapat dipahami upaya pimpinan dalam mengingatkan pegawai bahwa keberhasilan tugas pekerjaan tidak terlepas dari campur tangan tuhan sudah terbilang baik. Hal ini patut dipertahankan dan bila perlu ditingkatkan. 
Distribusi jawaban responden terhadap aspek Nilai Umum(Universal Values)

Setelah melihat jawaban responden, maka dapat diketahui bahwa presentase jawaban responden masing-masing indikator yaitu pada pertanyaan indikator satu berada pada $79,34 \%$ kemudian pertanyaan indikator dua berada pada $78,03 \%$, dan pertanyaan indikator tiga berada pada 78,36\%. Bahwa dari 3 (tiga) pertanyaan yang berhubungan dengan nilai umum (Universal Values), jawaban responden dari persentase skor berada antara 78,03\% sampai 79,34\% dengan jumlah persentase skor adalah $235,73 \%$ sehingga persentase nilai rata-rata skor adalah $235,73 / 3=$ 78,58. Dengan demikian, ini berarti bahwa pemberdayaan sumber daya manusia aparatur pada Badan Kepegawaian Daerah Provinsi Sumatera Selatan ditinjau dari nilai umum (Universal Values) berada pada kategori Baik.

\section{Variabel Pemberdayaan Sumber Daya}

\section{Manusia Aparatur}

Dengan melihat aspek-aspek pemberdayaan sumber daya manusia aparatur di atas, maka dapat diketahui bahwa presentase nilai rata-rata skor dari aspek nilai kepemimpinan (Leadership Values) berada pada 75,41\%, kemudian aspek nilai profesional (Proffesional Values) berada pada $78,28 \%$, dan aspek nilai umum (Universal Values) berada pada 78,58\%. Berdasarkan data variabel di atas dapat diketahui bahwa persentase rata-rata nilai kepemimpinan (Leadership Values) adalah 75,41, persentase ratarata nilai profesional (Proffesional Values) adalah 78,28, dan nilai umum (Universal Values) adalah
78,58. Dengan demikian jumlah persentase keseluruhan aspek adalah 232,27\%, sehingga didapat persentase rata-rata untuk variabel pemberdayaan sumber daya manusia aparatur adalah $232,27 / 3=77,42$. Dengan demikian, ini berarti bahwa pemberdayaan sumber daya manusia aparatur pada Badan Kepegawaian Daerah Provinsi Sumatera Selatan berada pada kategori Baik.

\section{PEMBAHASAN}

Nilai kepemimpinan merupakan suatu hal yang sangat krusial dalam organisasi. Hal ini dapat dikatakan menjadi salah satu faktor penting dan penentu dari keberhasilan suatu organisasi. Karena dengan penerapan kepemimpinan yang benar dan baik tentunya akan menjadi spirit bagi selunuh pegawai untuk bekerja lebih baik bagi organisasi. Nilai kepemimpinan menurut Said (2003) meliputi: 1) Adil; dalam membuat keputusan selalu berusaha menciptakan rasa adil diantara sesama pegawai tanpa adanya kesan diskriminasi; 2) Berani; tegas dan tanpa ragu-ragu dalam mengambil keputusan; 3) bersedia Menerima; menghargai setiap pendapat pegawai yang ada dalam lingkungannya maupun yang dilingkungan organisasinya. Konsep nilai kepemimpinan (Leadership Values) berdasarkan hasil olahan data dapat di simpulkan bahwa konsep tersebut sejalan dengan hasil penelitiannya dilapangan dengan nilai kepemimpinan berada pada kategori baik, dengan demikian konsep nilai kepemimpinan sangat mendukung Pemberdayaan Aparatur Sipil Negara atau Pegawai Negeri Sipil di masa yang akan datang. Keberhasilan dalam 
pemberdayaan sangat dipengaruhi oleh keinginan dan kehendak. Hal ini bukan hanya dapat mengontrol perbuatan-perbuatan sendiri, tetapi juga dapat mengontrol perbuatan-perbuatan atau kemampuankemampuan lain. Soerjono (2000) menyatakan bahwa pemberdayaan telah berhasil, manakala pimpinan memberikan kekuasaan kepada bawahannya sehingga mereka dapat melakukan pekerjaan dengan baik dan pimpinan mempercayai bawahannya. Tugas penting dari pimpinan organisasi dalam rangka pemberdayaan sumber daya manusia yaitu dengan pimpinan memilki nilai keprofesionalan dalam memberdayakan para pegawai. Karena dengan pimpinan yang profesional maka akan mudah untuk memberdayakan pegawai-pegawai yang khususnya ada pada Badan Kepegawaian Daerah Provinsi Sumatera Selatan. Dari hasil penelitian sub variabel nilai profesional kepemimpinan dapat dinyatakan bahwa sejalan dengan penerapan di lapangan dalam pemberdayaan sumber daya manusia atau pegawai pada Badan Kepegawaian Daerah Provinsi di Sumatera Selatan dengan demikian konsep nilai profesional kepemimpinan sangat mendukung penerapan pemberdayaan sumber daya manusia aparatur di masa yang akan datang. Salah satu hal yang vital dalam organisasi dimana pimpinan dalam melaksanakan pemberdayaan sumber daya manusia perlu memperhatikan nilai umum. Dimana nilai umum ini merupakan nilai yang sepatutnya pimpinan harus lakukan kepada para pegawai. Karena dampak dari pemberian nilai umum ini adalah lebih berdayanya para pegawai dalam melaksanakan tugas pekerjaannya. Pada aspek ini terdapat 3 (tiga) pertanyaan yang diajukan kepada responden. Berdasarkan hasil penelitian dari variabel pemberdayaan sumber daya manusia setiap sub variabel yang diteliti mengungkapkan bahwa semua sub variabel sangat mendukung penerapan pemberdayaan sumber daya manusia pada Badan Kepegawaian Provinsi Sumatera Selatan, kecuali indikator konsep adil yang masih perlu disempumakan. Hasil penelitian Said (2003) pada Badan Kepegawaian Daerah Provinsi Sumatera Selatan dengan mengambil tiga (3) sub variabel dari enam (6) sub variabel yang dikemukakan temyata mendukung konsepsi penerapan pemberdayaan sumber daya pada setiap organisasi baik saat ini maupun di masa akan datang.

\section{KESIMPULANDANSARAN}

Penulis menyimpulkan bahwa pemberdayaan sumber daya manusia aparatur pada Badan Kepegawaian Daerah Provinsi Sumatera Selatan yang didasari nilai kepemimpinan, nilai profesional, dan nilai umum, masingmasing berada dalam kategori baik. Namun demikian, masih terdapat beberapa permasalahan dalam hal keadilan pimpinan dalam pemberian tugas belajar yang masih kurang objektif dan belum berjalan secara optimal. Oleh karena itu, dalam pemberian tugas belajar/izin belajar seharusnya hal-hal seperti senioritas, masa kerja, pengalaman kerja, dan prestasi kerja turut dipertimbangkan. Di samping itu, perlu dibangun sistem seleksi internal secara khusus bagi Badan Kepegawaian Daerah Provinsi Sumatera Selatan 
sendiri maupun secara umum bagi keseluruhan

instansi yang ada di Provinsi Sumatera Selatan.

\section{DAFTAR PUSTAKA}

Hasibuan, Malayu S.P. 2009. Manajemen Sumber

Daya Manusia. Jakarta: Bumi Aksara.

Republik Indonesia. Peraturan Pemerintah RI Nomor 41 Tahun 2007 tentang Organisasi Perangkat Daerah.

Said, Ismail. Good Governance, dalam Volume 2 Nomor 1 Maret 2003. Jakarta: STIA LAN Jakarta. 